\title{
COURT HISTORIOGRAPHY IN EARLY TANG CHINA: ASSIGNING A PLACE TO HISTORY AND HISTORIANS AT THE PALACE
}

\author{
Isenbike Togan
}

\section{Introduction}

In Tang China (618-907 CE) policies and political interaction took shape at court, in the context of palace life. During the early Tang, court life came to include activities such as the writing of history: historians were assigned a place in the palace. The placement of the historians within the precincts of the palace was an illustration of the 'politicization of history', the institutional and political appropriation of history writing by the Tang court. This new trend did not only shape the interpretation of past events, but also the approach and methods of future historiography. It was during this time that the major histories of the preceding four centuries were written and the groundwork laid for future history writing by professional historians.

These changes were initiated by the second Tang emperor Li Shimin, known as Tang Taizong (626-649). He was regarded as an exemplary figure by later dynasties; his reign of Zhen Guan (True Vision) is known in Chinese history as the 'good rule of the Zhen Guan reign.' This 'Golden Age' lasted for 23 years from 627 to 649. Taizong, who reached power by killing the crown prince and forcing his father to abdicate, was able to achieve high standing in history, irrespective of these events. He gained this standing initially through a policy of sharing power with political contestants and consolidated his position with a victory (630) over the Early Türk, the foreign power in the north and the west. Immediately following this victory, he started his Tang history project with which he was actively involved. Power-sharing was reflected in the way history was written. It was no longer written by individuals, but by a commission whose members were employed at court. This paper discusses the timing of the history project, and shows that it was an ingenious move by Tang Taizong. The project was launched when the emperor had a strong hand following his victory 
over the Early Türk. The victory provided the starting point for the glorification of the emperor in historiography.

\section{Early Tang Court: Encampment and Palace}

The Tang Dynasty was established in 618. Tang court life, however, started in Taiyuan when Li Yuan, the then garrison commander, 'raised his flag' in revolt in 617. His associates who later became part of his entourage and bureaucracy can be considered as constituting the preliminary Tang court. After entering the capital of the defunct Sui dynasty, and proclaiming his dynasty as the Tang, Li Yuan mounted the throne on 18 June 618. He renamed his capital 'Chang'an' as it had been known during the Han dynasty. In history Li Yuan is known to us as Tang Gaozu (618-626).

From then on the new dynasty had its capital and court in Chang'an around the site of present Xi'an. With the conquest of the capital and the establishment of the dynasty, Li Yuan and his close associates started holding formal court. These associates, who were now occupying important positions at court, were familiar with the ways of court life from their earlier service to the former dynasties of Sui (581-618), the Northern Zhou (557-581) and the Northern Qi (550-577).

Initially, the court established itself in the former Sui palace, renamed Taiji dian or Great Joy Palace. It was situated in the southern part of the palace city. As the layout of the capital city shows (Fig. 1) the palace city was situated in the north of the city, a location which would also be adopted by later dynasties. As was also the custom in later dynasties, the private quarters of the imperial family were found in the north of the palace city (Fig. 2). The court of the earlier Tang consisted of Li Yuan's former associates as well as fresh talents who had joined the ranks of the new dynasty. Wechsler describes how the emperor would meet with his officials:

On the first and the fifteenth days of each lunar month, all officials of the ninth rank and above, that is, all officials 'within the current' (liunei), met with the emperor in special audience at the Taiji Hall, situated in the southern portion of the palace city. To the east and west of the Taiji Hall were two smaller council chambers (shangguo). After the audienceessentially ceremonial in nature-was concluded, the emperor retired to one of these council chambers, where soon afterwards he would be joined by his chief ministers, other designated high-ranking officials, remonstrating officials (jianguan) charged with pointing out errors in 


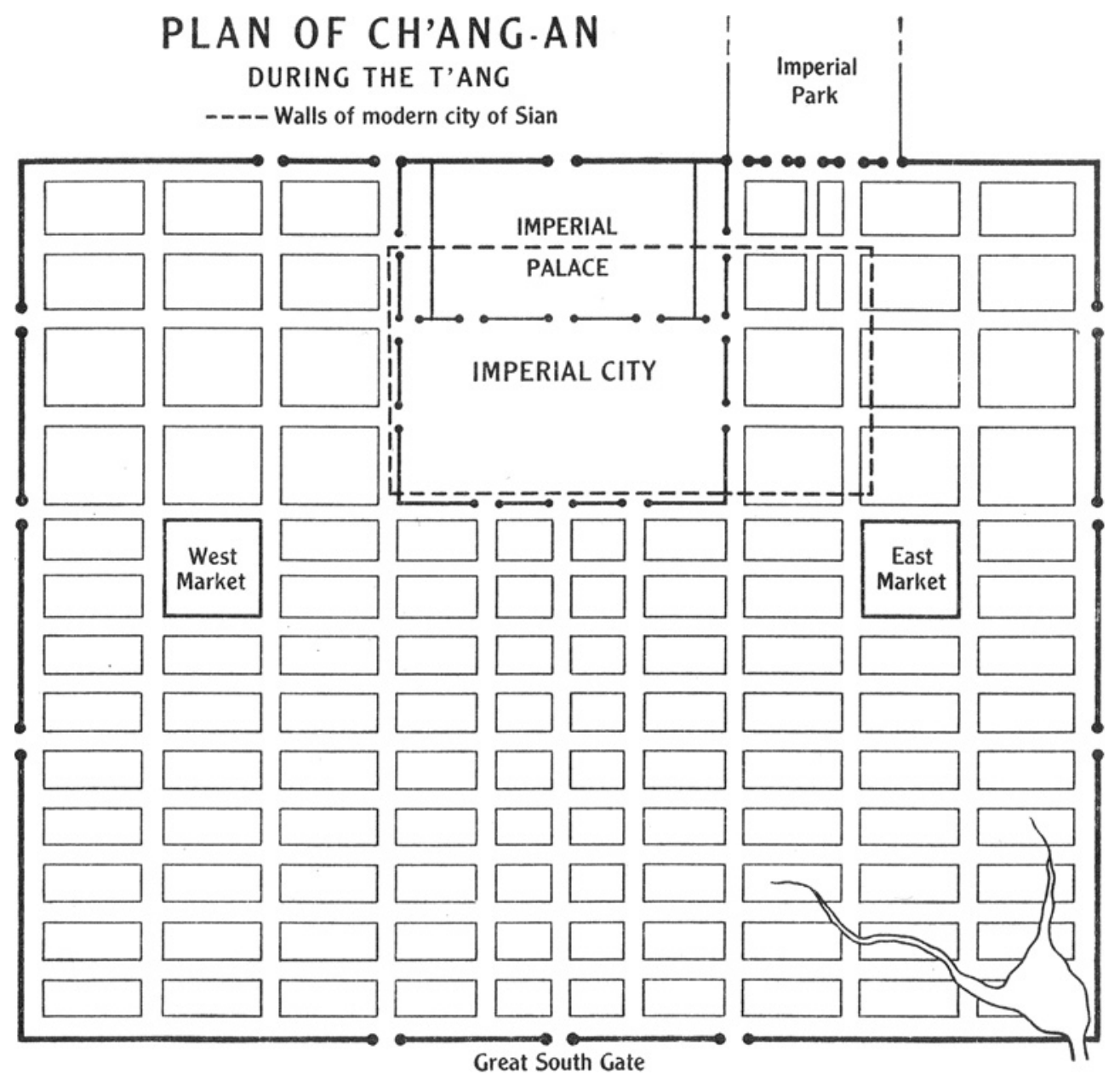

Figure 1. Chang'an, from Reischauer and Fairbank, East Asia. The Great Tradition (Boston 1960) p. 165. 


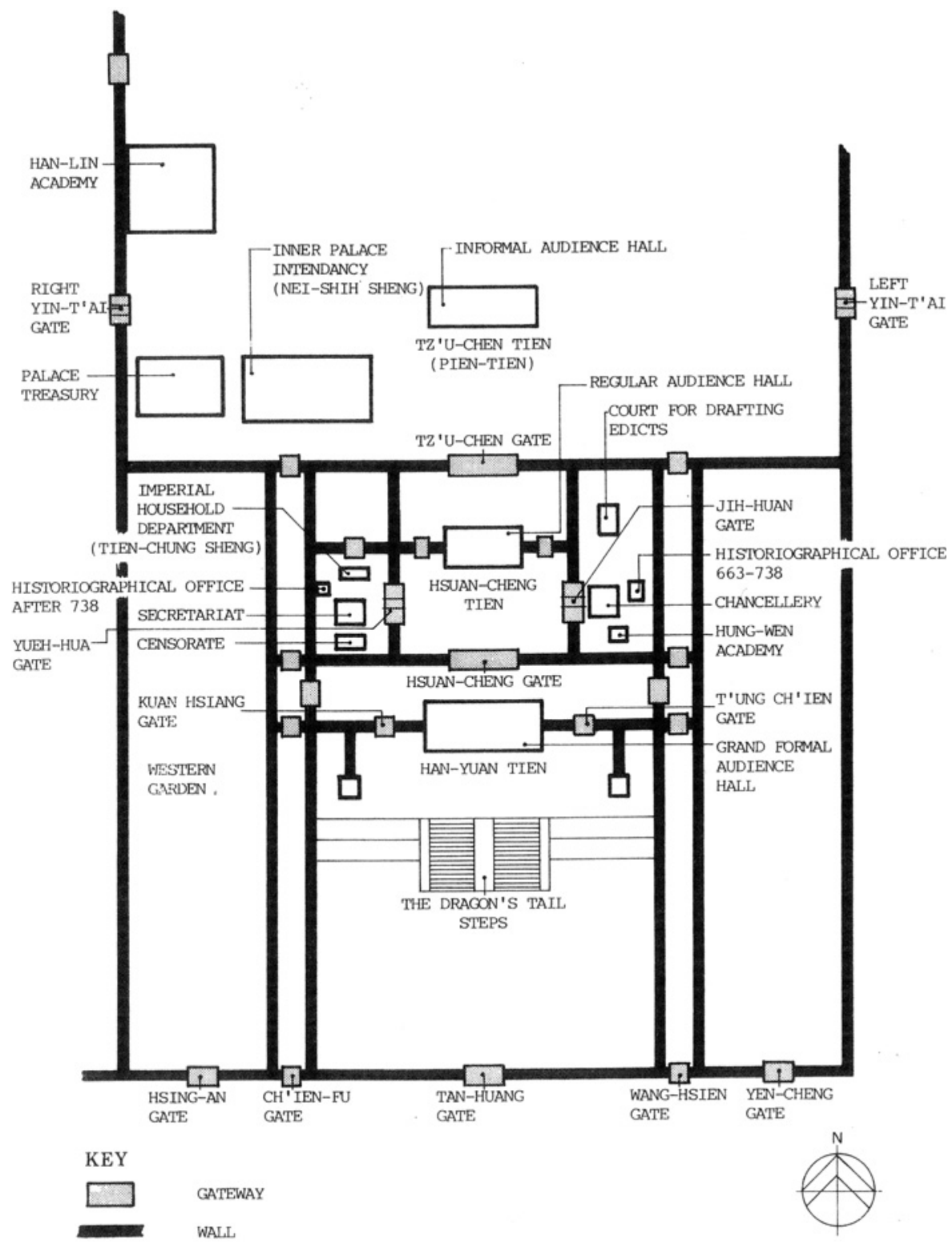

Figure 2. Public business area of the Ta-Ming palace, from: Denis Twitchett, The Writing of Official History under the T'ang (Cambridge 1992) p. 18. 
their deliberations, and one scribe to make a record of proceedings. Since the meetings in the council chambers were shorn of elaborate ceremony, the atmosphere was far more intimate than at the preceding large audiences, and the attending officials could speak their minds with relative ease. ${ }^{1}$

We know that in 618 envoys from the Early Türk in the north were received in the palace city and given a banquet with nine musical numbers. ${ }^{2}$ After 630 Taiji Hall was known for lavish and alcoholfueled entertainments hosted by the Tang emperor. ${ }^{3}$ Normally, court (called chao) was held early in the morning-and indeed the Chinese term for court was the same as that for early morning. Only on exceptional occasions-during periods of mourning, for example, were the meetings of the court suspended.

There were also palaces in other parts of the country. One of these was the former Renshou Palace of the Sui, renovated and renamed Jiucheng (Nine Perfections). This summer palace was located in the Tiantai Mountains about one hundred miles north of Chang'an. Additions to palaces were numerous especially during the reign of Tang Taizong. We are told that at the beginning of his reign Taizong was modest in his taste, but after his 630 victory over the Türk, he undertook a program of palace renovation and reconstruction. ${ }^{4}$ We see him holding court not only in various palace buildings but also on the move in encampments enclosed by cloth screens. On one such occasion after he left the palace in Chang'an and was heading towards Jiucheng Palace, there was an attempt on his life by one of the guards coming from the Türk royal family.

In 634 construction was begun on Daming Palace in the northeast of the imperial city. It began as a residence for the abdicated ruler Gaozu who refused to live in the Jiucheng Palace because it had originally been a Sui palace. However, he died before moving to this new

${ }^{1}$ Howard Wechsler, Mirror to the Son of Heaven. Wei Cheng at the Court of T'ang T'ai-tsung (New Haven; London 1974) p. 95. For the sake of consistency for the nonChina specialist, the original transcription in Wade-Giles has been changed to pinyin.

2 Among the nine numbers were Chinese as well as foreign pieces including music from Cambodia, Korea, Central Asian Kingdom of Kucha, Bukhara, Kashgar, Semerkand. Liu Mau-Tsai, Die Chinesischen Nachrichten zur Geschichte der Ost-Türken (T’u-Kue), 2 vols. (Wiesbaden 1958) vol. II, p. 572, n. 684).

${ }^{3}$ Wechsler, Mirror to the Son of Heaven, p. 126.

${ }^{4}$ Wechsler, Mirror to the Son of Heaven, pp. 130-131. 
palace building, ${ }^{5}$ which went through further renovations. In 663 the court was moved to the Daming Palace. ${ }^{6}$ The illustration of the layout of Daming Palace shows (Fig. 2) that the court consisted of inner and outer quarters. The government sections were in the outer court. There, the major divisions were the Imperial Secretariat-drafting memorials-on the right of the throne facing south (on the left of the map) and the Imperial Chancellery-reviewing and emending memorials - on the left side of the throne. ${ }^{7}$

The Historiographical Office (663-738) to be discussed below was established within the palace and its location changed according to changes in the court hierarchy. When the Chancellery was of great importance, the Historiographical Office was located in close proximity to it. Later, when the Imperial Secretariat gained importance, it was moved to the other side of the main courtyard to be close to the Imperial Secretariat. The changes in the location of the Historiographical Office, always staying in close proximity to the most important government office, reflect the new position that history writing had attained at the Tang Court.

The writing of history was not new in China, but its location at court was. In fact, the writing of history in China goes back to the centuries before our era. While modern scholars have concentrated more on the techniques of collecting, organizing and presenting the documents in historical works, the integration of history writing at court and its politicization have not been a focal point of studies of Chinese historiography.

The Tang dynasty gave historians a place at the court within the palace grounds in 629-630. History writing was first entrusted to political associates of the dynasty, and later to professional historians. The trend towards the politicization of history writing can be observed during the reigns of the first three rulers (618-683). However, it was Taizong who started this trend by appointing close associates to oversee the task of history writing. The new approach to history writing was closely related to the transition from a fragmented political order to power-sharing among former rivals. Power-sharing was a way to overcome the conflicts that were the rule during the fragmented politi-

\footnotetext{
5 Wechsler, Mirror to the Son of Heaven, p. 136.

${ }^{6}$ Denis Twitchett, The Writing of Official History under the T'ang (Cambridge 1992) p. 18.

7 Wechsler, Mirror to the Son of Heaven, p. 54.
} 
cal order of the previous 400 years. After the collapse of the Later Han dynasty at the beginning of the third century CE, China was ruled by many small dynasties. Some of these were local, others were of foreign origin. Remnants of the Xiongnu, various tribal groups of proto-Mongolian and proto-Turkic background roamed around in north China, where they sometimes established their rule. Most of the close associates of Gaozu the founder, and his son Taizong came from diverse political backgrounds as they had earlier been in the service of the Sui, Northern Zhou, and Northern Qi dynasties. This multifaceted group was also joined by some members of the old literati class coming mostly from the central areas and from the northeast. Together, they would constitute the bureaucracy and the elite of the first two reigns of the new dynasty. By giving a place to these men from diverse ethnic and political backgrounds, the Tang dynasty achieved a consensus among them. It made them share-holders of power whose status was later going to be preserved for eternity by their inclusion into the imperial funerary complex. The consensus eliminated the contestation among different groups and made possible consolidation under the Tang dynasty. ${ }^{8}$

The Li family, founders of the Tang dynasty, originated in the northwest and came from a mixed background; mixed marriages continued well into the first two reigns. The mother of the founding emperor Gaozu was of Xianbei origin, as was the beloved wife of the second ruler Taizong, whose brother-in-law played a significant role in court politics as well as in writing of history during the reign of the second and third emperors. This 'northwestern aristocracy', a label commonly used by modern historians, had been formed during the previous 400 years through interaction with foreigners such as the Sogdians, Xianbei, and Turkic groups. As a result of this mixed heritage, they were successful in combining civil and military powers in their administration as the Sui dynasty (581-618) had done before them. The Li family emerged dominant from these circumstances. The consensus that was reached on the internal scene, though still fragile, was strengthened by a defensive strategy against the outside world. The major external power, the Early Türk empire founded in 552, was pacified in 630, twelve years after the establishment of the dynasty.

${ }^{8}$ For an elaboration of this view see Wechsler, Mirror to the Son of Heaven, pp. 89, 92, 95 . 
The then Early Türk ruler was defeated and taken prisoner, and thus the eastern part of the Türk empire came under Tang control. About three decades later, the Western Türk were also brought under Tang control; Central Asian possessions now brought the borders of Tang China to Transoxiana.

Gradually, the strategies of power-sharing and consensus-building, themselves never wholly unchallenged, were supplanted by a policy of concentration of power in the hands of the dynasty. The institutionalization of the concentration of power was a long process. The politicization of history, initially tied closely to power-sharing strategies, was also one of the earliest steps taken in this process. Opposition became visible when the Empress $\mathrm{Wu}$ (684-705)-the consort of the third ruler-came to power. ${ }^{9}$ She moved the capital to the east, to Luoyang, unsettling the balance of power. It was also during her reign that the dynasty began to patronize Buddhism. The upheavals of her reign were mostly due to the contestations between the 'classical' northeastern literati, which formed a quasi-aristocracy, and the flourishing Buddhist church. After these upheavals, under the long rule of Xuanzong (713-756) the first signs of the dominating Confucian order were to be seen; however, this period ended with the rebellion of An Lushan (756-759). The regeneration of the empire after this rebellion is referred to as 'the Glory of the Tang.' The chapter on Tang institutions in the Cambridge History of China, a typical example, deals only with the period after 759 .

\section{The Tang History Writing Project: Court Historiography}

Before the Tang, under the Qin and Han dynasties, there had been histories produced during the lifetime of the dynasty. The first of these, the Records of the Historian ${ }^{10}$ by Sima Qian (ca. 145-90 BCE) and the History of the Former Han ${ }^{11}$ by Ban Gu (32-92 CE) had been

${ }^{9}$ Denis Twitchett and Howard J. Wechsler, 'Kao-tsung (649-83) and the empress Wu: the inheritor and the usurper', in: The Cambridge History of China III. Sui and T'ang China, 589-906, Denis Twitchett, ed. (Cambridge 1979) pp. 242-289.

${ }_{10}$ Burton Watson, Records of the Grand Historian of China, translated from the Shih chi of Ssu-ma Ch'ien (New York 1961).

${ }^{11}$ Homer H. Dubs, The History of the Former Han Dynasty, 3 vols. (Baltimore 1938-55). 
written by private individuals. ${ }^{12}$ The much cherished Record of the Three Kingdoms ${ }^{13}$ was also written by a private individual, Chen Shou (233-297 CE). The history of the Northern Wei (386-550 CE) by Wei Shou was also commissioned by one or two individuals. ${ }^{14}$ After Wei Shou's compilation in 554, there was a vacuum.

In 621-622, three or four years after the founding of the Tang dynasty, Linghu Defen proposed that the histories of the past six dynasties be written. ${ }^{15}$ This project was authorized by an edict on 1 February $623 .{ }^{16}$ However, after several years the project was suspended. Later between 19 January and 17 February $630,{ }^{17}$ the young emperor Taizong ordered the compilation of five (and not six) of these histories and made assignments. He took this decision in the midst of the campaign against the Early Türk. The importance of the timing cannot be emphasized enough. Let us look more carefully at these developments. Around March and April 629 Li Jing had been appointed Minister of War. Carrying out an assault from five sides, the imperial forces defeated the Early Türks by November. The assault was so successful that at the beginning of January 630, Tuli Qaghan, Elig (Xieli) Qaghan's nephew as well as the second in command, took refuge in China. The great victory was achieved on 26 February 630; $\mathrm{Li}$ Jing crushed the forces of Elig Qaghan. By the end of April and in the beginning of May Elig Qaghan was brought as a captive to Chang'an where he would die a few years later from sorrow. On May 24, 630 Tang Taizong was beseeched by the northern tribes to assume the title of tian kohan, that is Heavenly Qaghan. Thus by the end of May 630, he was both Son of Heaven (tianzi) and Heavenly Qaghan. We can see that the commissioning of the historians to write the history of the preceding dynasties took place exactly at this juncture.

12 Michael Nylan, 'Sima Qian: A True Historian?', Early China 23-24 (1998-99) pp. 203-246.

${ }_{13}$ Acilles Fang, The Chronicle of the Three Kingdoms, 2 vols. (Cambridge, Mass. 1965).

${ }^{14}$ Endymion Wilkinson, Chinese History: A Manual (Cambridge, Mass.; London 2000) p. 504.

${ }^{15}$ William Hung, 'The T'ang Bureau of Historiography before 708', HJAS 23 (196061) p. 94, from Tang huiyao 35.15 a.

${ }_{16}$ Hung, 'The T'ang Bureau of Historiography', p. 94.

17 The exact date is the intercalary 12th month of the 3rd year of the Zhenguan reign period. The 3rd year of the Zhenguan reign period, on the other hand, lasted from 30 January 629 to 17 February 630. This is why the date is given sometimes as 629 . But the chronological order of the events shows that the exact dating is important. 
The compilation of the histories was entrusted to the head of the Secretariat (zhongshuling) Fang Xuanling. Among those assigned to this task were Taizong's favorite minister and associate Wei Zheng, historian Linghu Defen, librarian Cen Wenben, Assistant Secretary Li Boyue, and writer Yao Silian. They were entrusted with the task of collaborating on the histories of the Sui, Zhou, and Qi dynasties of the north and the Liang-Chen dynasties in the south. Tang Taizong's brother in-law and close associate Zhangsun Wuji was also involved with the history writing process. It is to be noted that Taizong's associate and minister Wei Zheng was entrusted with the history of the defunct Sui dynasty. Wei Zheng, who worked with Taizong for 17 years as his close associate, was well acquainted with the circumstances of the Sui dynasty. He 'successfully fought against the compilation de novo of a history of the Northern Wei dynasty, a version of which had been compiled earlier by Wei Shou, ${ }^{18}$ who was also a member of the founder clan of the Wei.

History writing by a commission rather than by individuals, as had been the earlier custom, reflected the consensus reached at the establishment of the dynasty. Despite severe criticism by a historian a century later, this practice of assigning commissions to history writing would remain one of the fundamental traits of official Chinese historiography well into the nineteenth century. ${ }^{19}$ Moreover, while one might expect that history writing would develop after full institutionalization and consolidation of authority, a condition realized only in the eighth century, it was initiated by Tang rulers at the onset of their rule. ${ }^{20}$ Early Tang rulers decided that history writing was not to be delayed. This decision could be seen as a manifesto of the consensus reached after all the centuries of 'disunion.'

The new dynasty's resolution to take history writing under its control and shape the past in such a way as to make it a guideline for the

\footnotetext{
${ }_{18}$ Wechsler, Mirror to the Son of Heaven, p. 35.

${ }^{19}$ Edwin George Pulleyblank, 'Chinese Historical Criticism: Liu Chih-Chi and Ssu-ma Kuang', in: Historians of China and Japan, W.G. Beasley and E.G. Pulleyblank, eds. (London 1961) pp. 135-151.

${ }^{20}$ For the 8th century, institutionalization can be documented in the form of The Tang Manual of Government and (Da Tang Liu Dian) from 739. The Collection of Tang Regulations and Procedures (Tang huiyao) were compiled much later in 961. These works are all illustrations of the institutionalization that established the Confucian world view as the dominant order not only of the Tang dynasty but also of the following centuries in Chinese history.
} 
future deserves closer examination. Wechsler states that Chinese historiography was designed above all to teach moral lessons, lessons that could be conveyed most clearly by the judicious selection of materials and the coloring of narrative for effect. ${ }^{21}$ Chinese historiography and policymaking, in fact, relied heavily on the writings of the past. The statesmen and bureaucrats at court constantly referred to past incidents, contemplating them as examples to be followed or rejected. In the Old History of the Tang we encounter many examples of this kind. However, these examples come either from the classics like The Book of History, The Spring and Autumn Annals, The Zou Tradition, or from Sima Qian's Records of the Historian and Ban Gu's History of the Former Han (Hanshu). These latter works continue to this day to have a readership that enjoys their literary quality. The five dynastic histories produced during the reign of Taizong did not and still do not enjoy such a readership. They also do not seem to be quoted extensively in the official Old History of the Tang.

Historical works written by a commission did shape the past, but these works do not seem to have served as a mirror for the future with a wide readership across centuries. However, by making the writing about the preceding dynasties a first priority, the Tang also set a model for the future. However, this was not predestined; it evolved as a historical and historiographical process. There was a difference between intent and impact. The intent had been the legitimization of the power-sharers who established the Tang dynasty, and the glorification of the second ruler Tang Taizong rather than the founder. This is all the more striking, as according to the traditional Chinese belief, 'because of the great store of morality and virtue possessed by a founding ruler, Heaven transfers to him a Mandate to govern in place of the corrupt last ruler of a defunct dynasty. ${ }^{22}$ On the contrary, the accomplishments of the second ruler as well as the success of the history writing project gave rise to the 'traditional interpretation of the founding of the Tang, which held that Taizong rather than his father Gaozu was the genius behind the revolt that eventuated in the establishment of the dynasty'. ${ }^{23}$ This view achieved its final form in the 10th and 11th centuries when The Old and the New History of the

\footnotetext{
21 Wechsler, Mirror to the Son of Heaven, p. 5.

22 Wechsler, Mirror to the Son of Heaven, p. 6.

${ }^{23}$ Wechsler, Mirror to the Son of Heaven, p. 8.
} 
Tang, two official histories (zhengshi) were compiled on the basis of the materials collected and compiled during the time of Taizong and his close associates. While the intent of this history writing project was realized in the long run, its impact has been to set a pattern for dynastic history writing per se. This is why Yang Lien-sheng starts his study of traditional Chinese historiography with the Tang. ${ }^{24}$ From 630 on official historiography and its methods gained the upper hand. But this impact is not only visible in later history; it also covered earlier periods, so that the writing of official history was seen as a general trend of Chinese history. Let us look more closely at this project of history writing which eventually became the norm.

\section{The Actual Writing of Tang History}

Before the Tang, history writing was considered as a literary activity. Since ancient times there had always been court diarists but there was no Historiographical Office. A deliberate separation of the routine keeping of a Court Diary from the process of state-sponsored historical composition was formalized under the Northern Zhou and later under the Sui. ${ }^{25}$ History was written in the Bureau of Literary Compositions zhuzo cao, and historians would be employed in this office. ${ }^{26}$ At first the Tang continued this practice, but later they established a separate historiographical office. According to the Tang Manual of Government: 'At the beginning of the Zhenguan period [627-649], the Bureau of Historiography was separately established within the Palace, especially charged with Dynastic historiography. ${ }^{27}$ William Hung is of the opinion that even if the establishment of a Historiographical Office which he calls the Bureau of Historiography might have taken place during the time of Taizong, the process of recording history under a separate organization had started already at the time of Gaozu. ${ }^{28}$ By

${ }^{24}$ Lien-sheng Yang, 'The Organization of Chinese Official Historiography: Principles and Methods of the Standard Histories from the T'ang through the Ming Dynasty', in: Historians of China and Japan, W.G. Beasley and E.G. Pulleyblank, eds. (London 1961) pp. 44-59.

${ }_{25}$ Twitchett, Writing of Official History, p. 6.

${ }^{26}$ Hung, 'The T'ang Bureau of Historiography', p. 94.

${ }^{27}$ Hung, 'The T'ang Bureau of Historiography', p. 95.

${ }^{28}$ Hung, 'The T'ang Bureau of Historiography', pp. 95-96. 
the establishment of the Historiographical Office history was separated from the Bureau of Literary Compositions. Hung also states:

Emperor Taizong set up the Historiographical Office especially within the Palace, thus to emphasize the importance of the office and to protect its work from public knowledge. The work on the Histories of the Five Dynasties needed to be protected from premature disclosure lest some of the descendants of the historical figures might try to influence the historiographers in matters of praise and censure. ${ }^{29}$

To protect them from outside pressures, the historians were located in the Palace. ${ }^{30}$

About 10-12 years after these developments, the practice of keeping Veritable Records (shilu) started. Thus the Veritable Records which later became a prerequisite for writing official history ${ }^{31}$ were a Tang innovation. The Veritable Records of Tang Taizong were first written under the guidance of Tang Taizong himself. Twitchett gives a vivid illustration of the circumstances behind Taizong's complaints that he did not have access to them..$^{32}$

The story of the process of the writing of these early records is very complicated. There were different stages of the preparation of the Veritable Records. The Veritable Records of the Reigning Sovereign (the jinshang shilu) in twenty chapters were presented to the throne in 643 by Fang Xuanling and his colleagues. ${ }^{33}$ Emperor Taizong had these chapters read aloud to him. He was so deeply moved that he lost his composure and ordered that the scrolls be accepted and sent to the imperial library. He also ordered that a copy be given to the heir apparent and other princes. Metropolitan officials of the third rank and above were permitted to have copies made for themselves. I think that this copying helped the work to survive through the centuries. This early version of the historical records of the Tang dynasty has also survived in the Zhen Guan Zheng Yao. ${ }^{34}$ These were the records on the reign of Gaozu and Taizong.

${ }^{29}$ Hung, 'The T'ang Bureau of Historiography', p. 98.

${ }^{30}$ See figure 2 above from Twitchett, Writing of Official History, p. 18.

${ }^{31}$ On the process of preparation of official histories the general assumption is that there are 24 or 25 histories and that each was prepared by the succeeding dynasty and that official histories were prepared on the basis of the "Veritable Records", i.e. the Shilu that were compiled by the succeeding ruler for the previous reign.

32 Twitchett, Writing of Official History, p. 124.

${ }^{33}$ Twitchett, Writing of Official History, p. 124.

${ }^{34}$ Twitchett, Writing of Official History, p. 124. 
A next version called 'The Veritable Records of the Zhen Guan Period', (Zhen Guan Shilu), with additional chapters covering 641649 , was presented to the throne in 654 by Zhangsun Wuji. ${ }^{35} \mathrm{He}$ was a close associate from the early days of Taizong's career and also his brother-in-law. At that time he was the director of the Historiographical Office. There were two more sequences before the last version. Even this final version prepared by $\mathrm{Wu}$ Jing, exists in two incomplete forms. Wu Jing never finished it because of his perfectionist attitude. After his death his work was given to Wei Shu who started elaborating it. Apparently $\mathrm{Wu}$ Jing had taken his draft to his country residence and thus it survived destruction after the burning of the archives during the An Lushan rebellion. Twitchett says that it was:

... suggested that the censors and local officials should trace former officials of the office and offer a reward to anyone who could send the authorities any surviving portions of the National History or Veritable Records. If the historians themselves had taken the books from the office, they would be given amnesty for their offense. ${ }^{36}$

Eventually this copy made it possible to incorporate records surviving from the earlier part of the Tang into the official history. Hence we are now able to use the earlier part of the Old History of the Tang (Jiu Tangshu) as a reliable source. The complicated process of versions and variants in the genesis of the official history underlines the significant role played by writers outside of or in the margins of official history writing. The survival of their work allows us to study differences between the private and official versions from the same period.

\section{Private Histories Written at the Court}

Official histories were based on the court diaries (qiju $z h u)$ that were kept on a daily basis. We know that this was an old practice. Dur-

${ }^{35}$ See Twitchett, Writing of Official History, p. 126. However, this work is different from the Taizong Shilu that survived into the 11th century. The compiler of this latter work was a certain Xu Jingzong. Twitchett says, "his biographers, however, tell us that he twisted the facts and cut and changed the text of the Veritable Records of Gaozu and Taizong that had been compiled by Jing Bo, and that these changes were considered very serious." Twitchett, Writing of Official History, p. 127. Gaozong expressed dissatisfaction with Xu's work. Twitchett, Writing of Official History, p. 129. A revision was requested.

${ }_{36}$ Twitchett, Writing of Official History, p. 79. 
ing the Tang the court diaries were the only official record compiled continually throughout the dynasty. They were written by the court diarists (qiju lang and qiju shiren) who were part of the retinue of the emperor. While the former were responsible for recording the emperor's acts, the latter were responsible for recording his utterances. Court diaries were not meant for the emperor's eyes. However, the newly introduced Veritable Records-based on court diaries-were presented to the throne and attained official sanction.

Two works from the early Tang did not attain official sanction as they were written by individuals. Although these persons were closely associated with the court, they wrote in their capacity as private individuals. The first of these works is called Diary of the Founding of the Great Tang Dynasty and was written by Wen Daya. It seems that it was started at a time when Li Yuan, the founder of the Tang 'was still a Sui official and not an emperor and the work ceases with his assumption of the imperial throne. ${ }^{37}$ Besides this work there was another private history: Important Principles of Government from the Zhenguan Period (Zhenguan Zhengyao) by $\mathrm{Wu}$ Jing. Both of these works were written by personalities active under the early Tang; they deal with the founding process of the Tang.

Wen Daya, the compiler of Diary of the Founding of the Great Tang Dynasty was the son of a well-known scholar/official of the Northern Qi and the Sui. His father retired to Taiyuan when the Sui were on the verge of collapse. He had three sons and two of these three sons worked closely with Li Yuan, when he 'raised his flag' in Taiyuan. A third son Wen Yenbo (584-637) later became chief minister under Taizong; one of his sons became the consort of Gaozu's daughter. Wen Daya also became the president of the Board of Rites after Taizong ascended the throne in 626. As we can see Wen Daya came from a family which was in very close contact with the Tang royal family. He was an eyewitness to many events from the beginning of the Tang. He was one of the officials who conducted the ceremonies of abdication for the Sui child-emperor and for the ascension of Gaozu. The importance of Wen Daya's work was recognized by Sima Guang (1019-1086 CE) and was used by him quite extensively. Wen Daya's Diary must have been written during the reign of Gaozu but never

\footnotetext{
37 Twitchett, Writing of Official History, p. 41.
} 
became part of official historiography and indeed in many instances was in conflict with it.

The author of the second private history, $\mathrm{Wu}$ Jing, was a person with many official duties; he was involved in the writing of the national history (guoshi), but also in the writing of other works like the shilu of Empress Wu, Zhongzong and Ruizong. All this work was written in an official capacity. One would think that these official duties would have taken all his time but this was not the case. His private history, the Zhenguan Zhengyao is the work for which he is remembered and known. ${ }^{38}$

These private histories contain information that is not to be found in the Veritable Records, i.e., in official history writing. The Veritable Records show a bias in favor of Taizong. We know that these records in any case originated from a political purpose. Taizong 'ordered the Veritable Record for the first years of his reign after the death of his dethroned father Gaozu. ${ }^{39}$ Thus Taizong was able to control what was written about his father's achievements as well as his own seizure of power. In this connection Wechsler says:

the traditional accounts portray Shimin, who at the time of the revolt was about 17 years of age, as a brilliant military commander [....] they depict Li Yuan, then about 51 as a doddering and spineless old man, buffeted about by events over which he had no control, an unwilling pawn in the hand of his wily son, Shimin. ${ }^{40}$

The bias present in traditional Chinese works is repeated in English writings ${ }^{41}$ Eberhard, for example states that: 'The nominal leadership in the rising that now began lay in the hands of Li Shimin's father, $\mathrm{Li}$ Yuan; in practice Li Shimin saw to everything.' Wen Daya's work, on the other hand, helps us 'to counterbalance the bias written into the official record of the early Tang. ${ }^{42}$

${ }^{38}$ There is also an MA thesis (unpublished) on this work: Winston George Lewis, The Chen-kuan Cheng-yao: A Source for the Study of Early Tang Government, University of Hong Kong (Hong Kong 1962). Twitchett says that it includes a complete English translation, Twitchett, Writing of Official History, p. 172.

${ }_{39}$ Twitchett, Writing of Official History, p. 120.

${ }^{40}$ Wechsler, Mirror to the Son of Heaven, pp. 15-16.

${ }^{41}$ C.P. Fitzgerald, Son of Heaven: A Biography of Li Shih-min, Founder of Tang Dynasty (Cambridge 1933); Wolfram Eberhard, A History of China, New Enlarged Edition (Berkeley; Los Angeles 1955/1971) p. 172; Reischauer and Fairbank, East Asia. The Great Tradition, p. 155.

42 Twitchett, Writing of Official History, p. 41. 
Knowing that Taizong was very eager to control his future image, historians have puzzled over how these private histories were able to survive at all. For instance Wechsler says:

It seems strange that Taizong failed to suppress the Diary even after he began to take a supervisory role in the compilation of the dynastic history and veritable records. Did he underestimate the Diary's threat to his historical image because only the dynastic history and veritable records were intended to be transmitt[ed] to posterity? Did he never himself read the Diary since it was a short, private account of the founding of his house, and so remain[ed] completely ignorant of its content and the necessity for its destruction? All these questions, unhappily, remain unresolved. ${ }^{43}$

\section{Taizong's Personality and his Interest in Historiography}

The answer to these questions seems to lie in Taizong's personality. He was curious and anxious to see the records; he was even in favor of influencing the records. Yet as a brave man he respected the bravery and uprightness of other persons. Wen Daya had been a trusted associate of Taizong as well as of his father. Maintaining the relationship between the two may have been more important than destroying a historical record at odds with official history. Taizong had not incorporated this record into the approved Veritable Records of Gaozu (Gaozu shilu). Wen Daya's work dealt with his father only during the period before his enthronement in 618. Consequently, it did not deal with Taizong's rule. Yet by portraying Gaozu (Li Yuan) favorably, it potentially undermined the heroic image of Taizong, and shed a different light on his violent ascent to power-killing two brothers and forcing his father to abdicate during the Xuanwu gate incident of July 626 .

Taizong's long-term associate and minister Wei Zheng had worked until the last minute with the emperor of the defunct dynasty and had gone over to the Tang side only after the conquest of the capital. His first patron, moreover, was not Taizong but his brother, the assassinated crown prince. Taizong did not hold these acts against Wei Zheng. Instead as he 'needed all the men of high caliber he could recruit to

\footnotetext{
${ }^{43}$ Wechsler, Mirror to the Son of Heaven, pp. 26-27.
} 
aid him in governing the empire, ${ }^{44}$ he did not hesitate to employ him in his service. Wei Zheng benefited from the atmosphere of powersharing in the early years of the dynasty. In Wechsler's words: 'There was an impressive degree of official participation in decision making and official freedom to criticize the throne, more perhaps, than during most other periods of history. ${ }^{35}$ It was within this atmosphere that Wei Zheng worked with Taizong. ${ }^{46}$ Wei Zheng was the emperor's close associate for 17 years and has been seen 'as a prime motive force behind the success' of the Zhen Guan period. ${ }^{47}$ Wei Zheng's past was brought up only once in this relationship. ${ }^{48}$

In general Wei Zheng's frankness was appreciated by the emperor. But this exceptional emperor who was concerned about his historical image could not resist asking the official in charge of recording the deeds and actions of the emperor:

Generally, is the ruler allowed to examine [the records] or not? We wish to read these records so that We may take as a warning what they consider to be Our successes and failures. ${ }^{49}$

The response of this official named Zhu Shuliang to the emperor has acquired proverbial qualities. He said:

'I have never heard that rulers could themselves examine the histories [of their reigns].' Taizong said: 'If We have bad points, must you record them?' Suilang replied: 'I have heard that 'it is better to fulfill the duty of one's office than an obligation towards one's ruler. [italics added. I.T.] My duty in office is to uphold the brush, so how could I not record them? ${ }^{50}$

${ }^{44}$ Wechsler, Mirror to the Son of Heaven, p. 75.

${ }_{45}$ Wechsler, Mirror to the Son of Heaven, p. 4.

${ }^{46}$ These years of collaboration between the emperor and his adviser were seen as exemplary throughout Chinese history. In the 18th century we see the young prince who later became the Qianlong emperor reading this work as an account of "the model king whose record was required for all who aspired to rule." Harold L. Kahn, 'The Education of a Prince: The Emperor Learns His Roles', in: Approaches to Modern Chinese History, Albert Feuerwerker, Rhoads Murphey and Mary C. Wright, eds. (Berkeley; Los Angeles 1967) p. 26.

47 Wechsler, Mirror to the Son of Heaven, p. 2.

${ }^{48}$ Being angry at Wei Zheng Taizong is quoted saying: "Wei Zheng was not an official who righteously followed Our Office [as Prince of Qin], yet We selected him from the midst of criminals and gave him wealth and honor." Wechsler, Mirror to the Son of Heaven, p. 153.

${ }^{49}$ Wechsler, Mirror to the Son of Heaven, pp. 22-23.

50 This passage is from Zhengguan Zhengyao $7.7 \mathrm{~b}-8$ translated by Wechsler, Mirror to the Son of Heaven, p. 23, n. 45. 
The 11th-century historian Sima Guang tells us that although there were vehement protests from the remonstrating councilor (jianyi dafu) 'the emperor did not pay heed.' That is, he did not listen to the protests. Wechsler states: 'He [Taizong] ordered Fang Xuanling and his fellow historians Xu Jingzong and others, to edit the dynastic history into chronicle (bian-nian) form, the results of which were the Gaozu and Taizong Veritable Records.' He goes on to say that 'It is apparent, then, that during the period of their compilation both the dynastic history and the Veritable Records received Taizong's strong editorial influence. ${ }^{51}$

Finally when the Veritable Records were completed they were brought to his attention in the seventh month of 643. Examining these records he was not satisfied with the way the records dealt with the Xuanwu Gate incident. At the Xuanwu Gate, north of the palace, Taizong, then prince Li Shimin, had assassinated his elder brother the crown prince and forced his father Gaozu (Li Yuan) to abdicate. Looking back in 643 Taizong commented:

My action was as righteous as theirs because it has brought security to the state and benefit to all the people. Why then do the historians obscure [this fact] with their brushes? They should delete their embellishments and write a true account of the affair. ${ }^{52}$

This passage from the private history of Wu Jing (Zhengguan Zhengyao) tells us that the emperor did not object to the recording of the events themselves, but to the fact they had been described in obscure language. Taizong was insistent that they should be recorded directly, and without any attempt to hide them. This was the reason, Taizong stated, he asked for a correction. ${ }^{53}$ Thus from the account in the second private history written about this early period, we have a glimpse of the real man who was not interested in destroying a private account because it was not in line with his own outlook, yet made sure that this view was not represented in the official historiography prepared during his reign.

\footnotetext{
${ }^{51}$ Wechsler, Mirror to the Son of Heaven, p. 24.

${ }^{52}$ Translated by Wechsler, Mirror to the Son of Heaven, p. 24, n. 49 from Zhenguan Zhengyao $7.8 \mathrm{~b}$.

${ }^{53}$ Twitchett, Writing of Official History, p. 125, n. 18 where Twitchett denies that Taizong falsified history, as stated by Wechsler, Mirror to the Son of Heaven, pp. 22-27.
} 
It seems that Tang Taizong was a courageous person. This impression of his personality first emerged from the passages in the chapter on the Early Türk in the Jiu Tangshu where he boldly faced the enemy (the Early Türk), had a man-to-man relationship with the Early Türk rulers, delivered long speeches, but also listened carefully to his advisers. Visiting Chaoling, the monumental mausoleum that he built for himself, and studying the names of his horses and his poems reflecting his joy over the victories in Central Asia, one gets the impression that he was a man of great enterprises. However, the fact that Taizong built a smaller mausoleum for this father again suggests his concern about his personal reputation in relation to that of his father.

\section{The Emperor Changing the Unfavorable to his Favor}

The tone of majestic boldness found in the account of Important Principles of Government from the Zhenguan Period also permeates the chapter on the Early Türk (194a) in the Old History of the Tang (Jiu Tangshu, hereafter JTS), the Tang official history. It is interesting to note that although chapter 194-consisting of two parts-is called 'The Tujue (the Early Türk): 1st Part' it does not give much information about the Early Türk.

The chapters on foreign peoples in the official histories of the former dynasties written at the Historiographical Office do not usually have such a majestic tone. On the contrary they contain mostly basic information about foreign peoples. For instance when we look at the Zhoushu, Beishi and Suishu-all works completed by 636 as the first task of the Historiographical Office-we see that they talk about social life, customs, and legends of the Early Türk. These earlier histories as well as the earlier versions of the Veritable Records on which the Old History of the Tang was based, were written at about the same time. Therefore this kind of 'anthropological' information was sometimes repeated, yet omitted at other times. The chapter on the Early Türk in the JTS does not contain any such 'anthropological' information, which can be found in other chapters. The JTS moreover, was written from the political perspective and framework of the early Tang: it glorifies Tang Taizong as the emperor who won a victory over the Early Türk, making them dependents of China. The chapter only briefly deals with previous matters, such as the rule of warlords in North China, the famous Mayi or 'Horse [Bazaar] City', and the Early Türk's constant raids which posed difficulties for the early Tang. 
Interestingly, the section which deals mainly with the five years leading up to the submission of the Early Türk occupies more than half of the chapter, while the rest of the chapter deals with the period after 630 to 740 - that is with a period of more than a hundred years. The disproportionate weight given these five years in Taizong's early reign show the relevance of this phase for the glorification of the emperor. ${ }^{54}$ In this part we come across Taizong's policies dealing with the Early Türk rather than with information about the Early Türk themselves. Neither their life style nor their social organization or their customs and beliefs are mentioned. Likewise, there is no information about economic organization or trading activities. The Early Türk are presented as a people that the reader is already familiar with. Furthermore they are depicted as a culturally static society. The name Early Türk (Tujue) is used in alternation with names of their cultural 'forefathers' the Xiongnu. There are some lengthy passages about the psychological characteristics of the Early Türk. They are portrayed as people with a distinct culture and history. These passages give the impression of having been composed by a process of cut and paste.

The major emphasis is on the question how the Early Türk fell under Tang rule. The process leading to this achievement is described in great detail, not as a mere chronology of events, but as part of a larger discourse on how rulers have to deal with such complicated situations. As a result there are long passages of memorials presented to the throne and replies by Taizong, all discussing policies. These documents, on the one hand, display Tang Taizong's achievements; on the other hand, they convey in general terms how an unfavorable situation can be changed to one's advantage. For Taizong, the feat of changing an unfavorable situation into a favorable one was so important that it functioned like the major melody in a symphony, a theme recurring in his poems as well as in the Tang official history. ${ }^{55}$

In order to understand the complexity of the issues involved it would be helpful to first look at how Taizong became emperor and examine his situation before and after becoming emperor. How did these situations affect historiographical writing? The following four phases represent the major landmarks in Tang Taizong's political life:

\footnotetext{
${ }^{54}$ Jiu Tangshu, pp. 5153-5166.

55 See Helmuth Wilhelm and David R. Knechtges, 'T'ang T'ai-tsung's Poetry', T'ang Studies 5 (1987) pp. 1-23.
} 
1. Li Shimin as a prince

2. The Xuanwu Gate incident

3. Li Shimin's ascendance to the throne in August of 626

4. Tang Taizong's victory over Early Türk in April 630

However, instead of following this chronology, the chapter was composed in a narrative style in which perspectives of different persons were given. This style blurs the chronology: Li Shimin appears as if he had always been known as Taizong. Although Taizong's success in bringing the Early Türk under Tang control was greatly emphasized, his newly acquired title of Tian Kohan (Tengri Qaghan) received only little attention. In view of the fact that the chapter on the Early Türk in the JTS does not mention enthronement and speaks of him as Taizong even during the time when he was a prince, we can see that mentioning his ascendancy would also be an allusion to the Xuanwu Gate incident. Avoiding a chronological account meant that the Xuanwu Gate incident need not be mentioned.

We have first a narrative telling us how things happened under Taizong; then we are presented with a view involving Elig Qaghan (Xieli Kohan) and then another view from the side of Tuli Qaghan (Tuli Kohan). All these different perspectives are then followed by lengthy discussions at the court evaluating the submission of the Early Türk. While this evaluation is being carried out, there are many retrospective glances to the recent past as well as to the remote past involving the Xiongnu. These discussions, on the other hand, were being carried out to shape policies for the future, especially in terms of what to do with the submitted households and where to settle them. Let us examine more closely how at the beginning the situation was not so favorable for Taizong and how he was able to change these circumstances to his favor and to advance the prosperity of his state and empire.

Li Shimin was Gaozu's second son; his father had named his eldest son, and not Li Shimin heir to the throne. We are told that Li Shimin grew up in the border areas and spent a great deal of his childhood and youth in close contact with the Early Türk. We also know this from his own words when he makes a remonstrance against Tuli Kohan reminding him of their bonding and vow by incense (xiang huo). ${ }^{56}$ It is probably this statement that led to the rumors that he

${ }^{56}$ Jiu Tangshu, p. 5156 and İsenbike Togan, Eski T’ang Tarihi 194a, p. 126. 
was a childhood friend of Elig Qaghan (Xieli Kohan)'s nephew Tuli Qaghan (Tuli Kohan). While Li Shimin was spending time in the border areas practicing military arts, his elder brother was gaining stature among bureaucrats from East China at the capital. This situation made Li Shimin eager to take charge of the situation, and led to his assassination of his elder and younger brothers in 626 at the Xuanwu Gate in Chang'an. This gate was at a strategic location at the center of the north wall of Chang'an and opened the way to the Palace City. Li Shimin spread a false rumor about his brother who thereupon proceeded to the court to defend himself. With twelve of his most trusted followers-his brother-in-law Zhangsun Wuji being among themLi Shimin waited in ambush and killed his elder brother. In the aftermath Li Shimin was proclaimed heir apparent and on 4 September 626, Gaozu had to abdicate in Li Shimin's favor. ${ }^{57}$

These actions violated the Confucian principles, which required respecting one's father and elder brothers. But the times were such that military skill and the ability to pull together different factions were much needed. In the years preceding the collapse of the Sui, north China had been torn apart among warlords; these warlords in many cases were supported by the Early Türk. ${ }^{58}$ As a skillful politician and valiant leader who also knew the Early Türk and their ways, Li Shimin was able to overcome the remaining obstacles and ascend to the throne. From then on he would be called huangdi 'emperor' or jinshang 'the reigning sovereign' as stated in his first Veritable Records. Taizong was his temple name which was used posthumously.

Tang control over the Early Türk changed the balance of power in Asia in China's favor, and paved the way for subsequent prosperity. For Taizong, this achievement was first and foremost a result of his ability to change an unfavorable situation into a favorable one. This skill is emphasized in the historiography of his time, created under the supervision of the emperor. Taizong had a say in the compilation of the Veritable Records both for his father-with whom we know he had problems-and for himself. Examples of his involvement in history writing show how he viewed and influenced his father's and his own reputation, while trying to find a balance between personal and

${ }^{57}$ Howard Wechsler, 'The Founding of the T'ang Dynasty: Kao-tsu (reign 618-26)', in: The Cambridge History of China III. Sui and T'ang China, 589-906, Denis Twitchett, ed. (Cambridge 1979) pp. 182-187.

${ }_{58}$ Wechsler, 'The Founding of the T'ang Dynasty', p. 164. 
dynastic interests. ${ }^{59}$ He seems to have privileged dynastic reputation and issues of long-lasting impact.

\section{Taizong as a Man in Pursuit of a Long-Lasting Image}

We will now examine Taizong's interest in historical record keeping on the basis of the chapter on the Early Türk in the JTS. The chapter begins with Gaozu's igniting the uprising against the Sui in Taiyuan. Soon we are informed that Gaozu had to ask the help of the Early Türk which was duly rendered: the Early Türk Qaghan sent troops and horses.$^{60}$ Later, however, we are told that on 24 September 626 Taizong told the Early Türk envoy 'when the righteous army entered the capital for the first time, your [ancestors], father and son sincerely submitted to us and followed us. ${ }^{61}$ It is apparent that this statement is in conflict with what was said at the beginning of the chapter, which stated that Gaozu requested help from the Early Türk.

Moreover, there is additional information which is not to be found in JTS but only in Wen Daya's work. ${ }^{62}$ There it is said that Gaozu sent a letter to the Early Türk Qaghan, Shibi, 'professing a desire to save the Sui and, to that end, offering to restore harmonious relations with the Early Türk.' H. Wechsler comments: 'The proposal was sweetened with the promise that if Shibi allied with Li Yuan, all the booty to be gained from the campaigns against the rebels would be turned over to the Qaghan. The letter was very respectful in tone, and when it was completed Li Yuan affixed to it the character $q i$ "communication from inferior to superior." ${ }_{63}$ There is a scholarly controversy about the exact meaning of this issue, ${ }^{64}$ but the exact meaning of the term is not an issue here. Our concern is that although Gaozu's asking for help is a fact established by the JTS as well as by Wen Daya's work, according to the record cited above on 24 September $626 \mathrm{Li}$ Shimin, the later Taizong, stated just the opposite.

\footnotetext{
${ }^{59}$ Jiu Tangshu, p. 5157 and Togan, Eski T'ang Tarihi, p. 134.

${ }^{60}$ Jiu Tangshu, p. 5153 and Togan, Eski T'ang Tarihi, pp. 87-89.

${ }^{61}$ Jiu Tangshu, p. 5157 and Togan, Eski T'ang Tarihi, p. 134.

${ }_{62}$ Wen Daya, Datang chuangye qijuzhu (Shanghai 1983) vol. 1, pp. 11-12.

${ }^{63}$ Wechsler, Mirror to the Son of Heaven, p. 28; Wen Daya, Datang Chuangye qijuzhi, vol. 1, p. 9.

${ }^{64}$ Wechsler, Mirror to the Son of Heaven, p. 28, n. 60 and Wechsler, 'The Founding of the T'ang Dynasty', p. 158.
} 
Obviously Gaozu's asking for help could diminish his personal standing in history. Conversely, it potentially enhanced Taizong's personal status, as he had proved able to drastically change the balance in his favor. Assuming that Taizong's conflict with his father outweighed other concerns and that he was willing to change the records to improve his standing, Taizong should have destroyed Wen Daya's work. In that case, moreover, he would have insisted firstly on mentioning Gaozu's use of a term indicating respect for the superior in his address to the Early Türk. Secondly, he would not have made any statement about the Early Türk being the followers of the Tang when they entered Chang'an for the first time, as this statement put his father in a better light. From these discussions we can see that it was not his personal standing but issues of lasting importance for the dynasty that seem to have been central for him.

Another matter demands our attention. The 24 September statement of majestic boldness cited above was made just two days before the agreement on the Bian Bridge to the west of Chang'an. ${ }^{65}$ Wechsler says:

According to the traditional account, at this point Taizong employed a strategem to separate Xieli from his main force, surround him with a small band of his men, and convince him to sue for peace $[\ldots .$. However, there is evidence that in fact Taizong not only failed to capture the Tujue Kaghan but also he was forced to part with a great deal of treasure to secure the Tujue withdrawal. ${ }^{66}$

Taizong himself alluded to the fact that the agreement of the Bian Bridge on the Wei River had been won by giving out riches. ${ }^{67}$ Issuing the strongly worded statement just two days prior to the negotiated agreement gives the impression that Taizong had a strong hand, which was not the case. Here we can see Taizong's impact on historical record keeping; he influenced the tone, the light under which an event was shown rather than changing the wording or the record. In the account we also hear that suddenly the Early Türk Qaghan Elig (Xieli)

${ }^{65}$ Jiu Tangshu, p. 5157 and Togan, Eski T'ang Tarihi, p. 141.

${ }^{66}$ Howard Wechsler, 'T'ai-tsung (Reign 626-49). The Consolidator', in: The Cambridge History of China III. Sui and T'ang China, 589-906, Denis Twitchett, ed. (Cambridge 1979) p. 221.

${ }^{67}$ JTS 194s:5158 and Togan 2006, 5158: 6-8; see also Tang Chi, 'Wei Nehri Barış Anlaşmasına Dair Araştırmalar', Tarih Dergisi (İ̈EF) Fatih Sultan Mehmed'e Hatıra Saylsı 33 (March 1980/81) [1982] pp. 215-226. 
became apprehensive, considered withdrawing and asked for peace. Tang Chi's study shows in detail that this was not case. Elig Qaghan (Xieli) had nothing to be apprehensive about.

It is also to be noted that the agreement was made by sacrificing (cutting) a white horse. ${ }^{68}$ In the JTS text this incident is described with the words xing baima. This is a custom found among different Inner Asian peoples. Tang Chi has given examples from the Xiongnu. ${ }^{69} \mathrm{We}$ also know of similar incidents from the Secret History of the Mongols where a vow is made by cutting a white horse in two. I am not familiar with such a custom prevalent among the Chinese, although Wechsler calls it the traditional sacrifice; Tang Chi also sees this as an Inner Asian custom. ${ }^{70}$ As Taizong was familiar with the ways and customs of the Early Türk, he did not shy away from pleasing them both materially and psychologically. Alluding to this incident, he later remarked: if you want to get hold of something, you have to give. ${ }^{31}$ Taizong flexibly adapted to a difficult situation, with the Early Türk present in the interior of the country, while he himself had only recently, and not without difficulty, ascended the throne. As he could not hope to completely control this situation, he chose not to fight, even if this could be achieved only by giving out jade and silk:

Today if I roll up my armor and put away my bow case and lance and can lure them with silk and jade, the haughty manners of the obstinate enemy will starting from now come to an end. ${ }^{72}$

The lesson is clear: a ruler needed to have patience, give in if necessary and wait for the right moment.

When the right moment came in 630, Taizong was quick in defeating and subjecting the Early Türk. At this time the Türk were in distress because of weather conditions and internal strife. Revolt by subjugated tribes in the north added another dimension to their difficulties. After emerging successfully Taizong did not shy away from accepting the title of the defeated enemy 'Heavenly Qaghan (tian kohan)'. The way in which he accepted this title, symbolizing hegemony over the 'steppe and the sown' is also of significance. After April 630 when Elig Qaghan

\footnotetext{
${ }^{68}$ Jiu Tangshu, pp. 5157 and 5158 and also Togan, Eski T'ang Tarihi, pp. 141 and 143.

${ }^{69}$ Tang Chi, 'Wei Nehri Barış Anlaşması'.

${ }^{70}$ Wechsler, 'T'ai-tsung', p. 221.

${ }_{71}^{71}$ Jiu Tangshu, p. 5158 and Togan, Eski T'ang Tarihi, p. 145.

72 Jiu Tangshu, p. 5158 and Togan, Eski T'ang Tarihi, pp. 144-145.
} 
(Xieli) submitted to China, messengers came from the North who asked Taizong to accept the title of Heavenly Qaghan (tian kohan), because he was now the rightful ruler. Although there is some confusion in the sources regarding the bearers of this request, his assumption of this title had a historical significance. ${ }^{73}$ Thus Taizong acquired this not by warfare $w u$; it was presented to him voluntarily. He was now the universal ruler, both Son of Heaven (tianzu) of the 'sown' and Heavenly Qaghan (tian kohan) of the steppe, thus symbolizing the harmony all under Heaven.

With these achievements Taizong towered above the local powers in China as well as in the steppe and was able to change the balance of power in Asia in China's favor. He expanded his lands as far west as Ferghane in present Uzbekistan, a process bringing western Asian cultural influences to China as well as acknowledgement of Chinese culture in western Central Asia. ${ }^{74}$ Taizong's universalist position made him promote all-embracing policies toward different religions, too. In this connection Kenneth Chen says in his Buddhism in China:

In his policy toward Buddhism during the early years one might discern the emperor's desire to use the religion for the benefit and advantage of the state. ${ }^{75}$

Chen also states that:

Though the imperial clan claimed descent from Laozu-actually this idea was emanating from Taizong - and thus favored Taoism, the central authorities pursued a policy of religious toleration, giving each religion an opportunity to develop. Nestorian Christianity, Islam, and Manichaeism all were introduced during Tang times, and each faith found adherents among the Chinese. ${ }^{76}$

These policies that were put forward by Taizong can be called allembracing and universalist. It was within this atmosphere that the Tang history project was initiated and brought to completion.

\footnotetext{
${ }^{73}$ Our sources say that the request was made by northern tribes but the names that are mentioned are western tribes.

${ }_{74}$ Berthold Laufer, Sino-Iranica: Chinese Contributions to the History of Civilization in Ancient Iran, with Special Reference to the History of Cultivated Plants and Products (Chicago 1919).

${ }^{75}$ Kenneth Ch'en, Buddhism in China (Princeton 1964) pp. 217-218.

${ }^{76}$ Ch'en, Buddhism in China, p. 213.
} 


\section{Conclusion}

There is a general tendency to regard Chinese historiography as being designed to teach moral lessons. 'The judicious selection of materials and the coloring of narrative for effect' were geared towards illustration of these lessons. However, under the early Tang there was an additional dimension to history writing. The Tang dynasty showed a resoluteness to take history writing under control and shape the past in such a way as to make it a guideline for the future. This was not done on the basis of authoritarian principles but reflected power-sharing.

While earlier histories had been composed by individuals, the Tang history was written by a commission. The writing of history by a group of officials reflects the consensus reached by those who shared power. The timing of this project is noteworthy as it immediately followed the 630 military victory over the Early Türk who had been ruling since 552 . This significant victory occurred outside the territory of early Tang China. However, the glorification of this victory was accompanied by the construction and renovation of palaces, the building of funerary complexes, the establishment of new rituals in connection with these complexes, and the introduction of a history writing project. ${ }^{77}$ The victory in the exterior strengthened the imperial hand in instituting and implementing new policies in the interior, leading to centralization and the concentration of power. It was precisely these developments which later led to the glory of the Tang.

The success of the Tang was possible only because Emperor Taizong was a man who had the ability to change the unfavorable to his favor. This skill gave him a strong hand in initiating his history writing project. By the ingenious method that he initiated he was able to sanction the completion of the Veritable Records providing the basis for official history. Setting the tone for the future, he paved the way for official history written by commissions-a method employed by later dynasties. As he was a person interested in long-lasting implications rather than short-term policies, he emerged from this project as the model emperor of the 'good rule of the Zhenguan reign' who was known for his tolerance for criticism and for permitting the participation of court officials in decision making.

77 Howard Wechsler, Offerings of Jade and Silk: Ritual and Symbol in the Legitimation of the T'ang Dynasty (New Haven, Connecticut 1985). 